Jurnal Pustaka Budaya. Vol. 7, No. 2. Juli 2020

Copyright (C2020, pISSN: 2355-1186 / eISSN: 2442-7799

Available Online at: https://journal.unilak.ac.id/index.php/ph

\title{
MANAJEMEN STRATEGIS DALAM PENGEMBANGAN PROGRAM KONSORSIUM E-JOURNAL OLEH FPPTI JAWA BARAT
}

\author{
Yunus Winoto*), Julian Abdillah**), Ute Lies Siti Khadijah***) \\ Fakultas Ilmu Komunikasi, Universitas Padjadjaran, Sumedang Indonesia
}

email: yunuswinoto@gmail.com*), julianabdillah10@gmail.com**), ute.lies@unpad.ac.id***).

Naskah diterima: 16 Februari ; direvisi: 19 Februari ; disetujui: 21 Februari 2020

\begin{abstract}
Abstrak.
Penelitian ini bertujuan untuk mengetahui kegiatan manajemen strategis dalam program konsorsium e-journal oleh Forum Perpustakaan Perguruan Tinggi Indonesia (FPPTI) Jawa Barat. Teori yang digunakan dalam penelitian ini menggunakan teori manajemen strategis yang meliputi tahap pengamatan lingkungan, perumusan strategi, implementasi strategi, dan evaluasi strategi. Metode yang digunakan dalam penelitian menggunakan pendekatan kualitatif dengan jenis penelitian studi kasus. Adapun teknik pengumpulan data dilakukan melalui observasi, wawancara serta melalui studi kepustakaan. Berdasarkan hasil penelitian diketahui bahwa dalam mengembangkan program konsorsium e-journal, FPPTI Jawa Barat pada tahap perencanaan dimulai dengan melakukan pengamatan serta analisis lingkungan internal dan eksternal yang mencakup kekuatan, kelemahan, peluang, serta ancaman. Selanjutnya dari hasil analisis tersebut dilakukan dengan perumusan strategi berupa penetapan visi dan misi, tujuan, strategi dan kebijakan. Tahap kedua yaitu tahap implementasi yang membahas terkait penetapan program, penentuan anggaran serta pembahasan prosedur pelaksanaan program konsorsium e-journal. Kemudian pada tahap terakhir adalah evaluasi program konsorsium e-jurnal dengan mengukur kinerja serta pelaporan berdasarkan analisis dan strategi yang telah dirumuskan sebelumnya.
\end{abstract}

Kata kunci: manajemen strategis, konsorsium, e-journal, Forum Perpustakaan Perguruan Tinggi Indonesia (FPPTI)

\begin{abstract}
This study aims to determine the strategic management activities in the e-journal consortium program by the Indonesian Higher Education Library Forum (FPPTI) in West Java. The theory used in this study uses strategic management theory which includes the stage of environmental observation, strategy formulation, strategy implementation, and strategy evaluation. The method used in research uses a qualitative approach to the type of case study research. The data collection techniques are carried out through observation, interviews, and through library research. Based on the research results it is known that in developing the e-journal consortium program, FPPTI West Java in the planning stage begins by observing and analyzing the internal and external environment which includes strengths, weaknesses, opportunities, and threats. Furthermore, the results of the analysis are carried out with the formulation of strategies in the form of establishing a vision and mission, goals, strategies, and policies. The second stage is the implementation phase which discusses the program determination, budgeting, and discussion of the procedures for implementing the e-journal consortium program. Then in the final stage is the evaluation of the e-journal consortium program by measuring performance and reporting based on the analysis and strategies that have been formulated previously.
\end{abstract}

Keywords: strategic management, consortium, e-journal, Indonesian University Library Forum (FPPTI) 


\section{PENDAHULUAN}

Forum Perpustakaan Perguruan Tinggi Indonesia (FPPTI) merupakan sebuah forum kerjasama antar perpustakaan perguruan tinggi baik perguruan tinggi negeri maupun perguruan tinggi swasta yang ada di Indonesia. Berdirinya organisasi profesi ini dilatarbelakangi karena masih belum optimalnya pengembangan sumber daya perpustakaan, masih kurangnya kerjasama antar perpustakaan perguruan tinggi, masih kurangnya pengetahuan terhadap pengelolaan perpustakaan Perguruan Tinggi dan masih banyaknya perpustakaan Perguruan Tinggi di Indonesia yang belum mampu menjalankan perannya secara optimal dalam menunjang Tri Dharma Perguruan Tinggi (Pendidikan dan Pengembangan, Penelitian dan Pengarjaran, Serta Pengabdian Kepada Masyarakat).

Dengan hadirnya Forum Perpustakaan Perguruan Tinggi Indonesia (FPPTI) tersebut diharapkan akan mampu membantu dalam meningkatkan kualitas perpustakaan yang ada di Indonesia, terutama dalam hal peningkatan sumber daya perpustakaan, kerjasama antar perpustakaan, dan meningkatnya peran perpustakaan Perguruan Tinggi dalam menunjang tercapainya Tri Dharma Perguruan Tinggi.

FPPTI memiliki visi untuk menjadikan perpustakaan Perguruan Tinggi sebagai support system dalam tercapainya tujuan Tri Dharma Perguruan Tinggi, sejalan dengan perkembangan teknologi informasi dan komunikasi. Selanjutnya FPPTI membawa misi untuk mengembangkan kerjasama jaringan layanan informasi berbagai disiplin ilmu untuk menciptakan Sumber Daya Manusia (SDM) Perguruan Tinggi yang berkualitas, membina dan meningkatkan kualitas layanan perpustakaan, dan berbagai kesediaan literatur antara perpustakaan yang sudah maju dan sedang berkembang, kemudian meningkatkan profesionalisme pustakawan dan kualitas layanan perpustakaan Perguruan Tinggi, serta membantu memperkaya koleksi masing-masing perpustakaan dan mening-katkan kemampuan dalam mengakses informasi. Sedangkan tujuan
Yunus Winoto, Julian Abdilah dan Ute Lies Siti Khadijah dari FPPTI adalah untuk meningkatkan fungsi dan peran perpustakaan di masing-masing Perguruan Tinggi dalam melayani civitas akademika dan meningkatkan mutu akreditasi masing-masing Perguruan Tinggi.

Sejak pertama berdiri pada tahun 2000, Forum Perpustakaan Perguruan Tinggi Indonesia (FPPTI) pada saat sekarang ini sudah tersebar di 22 provinsi di seluruh Indonesia sebagaimana hal tersebut diungkapkan pada pidato sambutan perwakilan FPPTI pusat dalam acara Seminar, Workshop, dan Musyawarah Daerah VII FPPTI Jawa Barat, pada tanggal 10 September 2019, salah satunya adalah Forum Perpustakaan Perguruan Tinggi (FPPTI) wilayah Jawa Barat. FPPTI Jawa Barat merupakan sebuah perkumpulan perpustakaan Perguruan Tinggi yang berada di wilayah Provinsi Jawa Barat. Adapun untuk FPPTI wilayah Jawa Barat sampai saat ini telah memiliki anggota sebanyak 262 orang yang merupakan perwakilan dari berbagai perguruan tinggi negeri (PTN) dan perguruan tinggi swasta (PTS) yang berada di wilayah Jawa Barat.

Sebagai forum tempat berkumpulnya para pengelola perpustakaan perguruan tinggi, FPPTI Jawa Barat memiliki konsen terhadap meningkatkan kualitas dan optimalisasi layanan terhadap pemenuhan kebutuhan pengguna perpustakaan. Apalagi dengan berkembangnya ilmu pengetahuan dan teknologi saat ini, ekspektasi dari tuntutan masyarakat pengguna terhadap pelayanan perpustakaan yang cepat dan akurat semakin tinggi, sehingga diperlukan tersedianya sebuah fasilitas yang lengkap dan memadai serta kegiatan layanan yang optimal. Namun demikian pada kenyataan-nya tidak semua lembaga perpustakaan perguruan tinggi memiliki kesiapan dan kemampuan yang sama dalam pengem-bangan sumber informasi.

Untuk mengatasi keterbatasan dalam penyediaan sumber informasi yang dihadapi beberapa lembaga perpustakaan perguruan tinggi diperlukan suatu kebijakan dalam penyediaan sumber informasi sehingga kebutuhan koleksi tersebut dapat dimanfaatkan secara optimal, apalagi jika kebijakan tersebut dilaksanakan secara bersama-sama tentu saja 
pengembangan terhadap kebutuhan koleksi menjadi lebih efektif dan efisien, dan dengan demikian ketersediaan koleksi tetap terjaga sesuai dengan tujuan yang telah ditetapkan.

Salah satu upaya yang dilakukan FPPTI Jawa Barat dalam mengatasi keterbatasan sumber informasi yang dimiliki beberapa lembaga perpustakaan perguruan tinggi yang menjadi anggota forum adalah membuat sebuah program yakni dengan berlangganan jurnal elektronik secara bersama-sama dengan sistem konsorsium atau disebut juga dengan konsorsium e-journal.

Penelitian ini mencoba mengkaji tentang manajemen strategi dalam pengembangan konsorsium e-journal. Adapun mengenai konsep manajemen strategi menurut J. David Hunger dan Thomas L. Wheelen dalam (Dewi dan Sandora 2019), adalah serangkaian keputusan dan tindakan manajerial yang menentukan kinerja perusahaan dalam jangka panjang. Sedangkan proses manajemen strategis meliputi tahap pengamatan lingkungan, perumusan strategi (perencanaan strategis atau perencanaan jangka panjang), implementasi strategi, dan evaluasi serta pengendalian. Manajemen strategis menekankan pada pengamatan dan evaluasi peluang dan ancaman lingkungan dengan melihat kekuatan dan kelemahan perusahaan.

Dalam kajian yang peneliti lakukan yaitu tentang konsorsium jurnal elektronik. Adapun mengenai pengertian konsorsium dalam konteks perpustakaan menurut Arnold Hirshon dalam jurnal (Pal dan Das 2007, 2) mengartikan konsorsium perpustakaan sebagai istilah umum untuk menunjukkan setiap kelompok perpustakaan yang bekerjasama mencapai tujuan bersama, baik untuk memperluas kerjasama pada layanan perpustakaan tradisional atau layanan informasi elektronik. Adapun dalam prakteknya konsorsium ini sangat bervariasi baik dalam hal tujuan, jenis perpustakaan peserta, struktur, keanggo-taan, dan pendanaan. Sedangkan mengenai pengertian jurnal elektronik atau e-journal adalah jurnal yang
Yunus Winoto, Julian Abdilah dan Ute Lies Siti Khadijah segala aspek (penyiapan, review, penerbitan, dan penyebaran) dilakukan secara elektronik.

Sebagai salah satu sumber informasi di perpustakaan, banyak keunggulan bagi perpustakaan perguruan tinggi jika menggunakan dan berlangganan jurnal elektronik untuk memenuhi kebutuhan informasi bagi penggunanya, yaitu pencarian teks jauh lebih mudah dan praktis. E-journal juga mencakup multimedia dan grafis yang menarik perhatian para pengguna, serta hypertext yang tersedia di e-journal akan langsung membawa pembaca ke link yang dituju.

Keberadaan jurnal elektronik di Perguruan Tinggi pada saat sekarang ini sangat diminati oleh mahasiswa, dosen, dan sivitas akademika lainnya. Jurnal elektronik atau $e$ journal memiliki keunggulan dari segi aksesibilitas, keakuratan, dan informasinya yang mutakhir atau up to date. Keberadaan jurnal di perpustakaan Perguruan Tinggi sangat membantu mahasiswa, dosen, dan civitas akademika lainnya dalam memenuhi kebutuhan informasi mereka masing-masing, baik itu untuk memenuhi kebutuhan untuk tugas perkuliahan, tugas akhir, publikasi ilmiah, dan lain-lain. Sebagai contoh, mahasiswa mengerjakan tugas perkuliahan yang diberikan oleh dosen yang mahasiswanya diharuskan untuk mencari literatur ilmiah dari e-journal. Kemudian dalam penulisan karya ilmiah tersebut harus mencantumkan sumber melalui e-journal sangat diperlukan disetiap mengerjakan sebuah riset atau penelitian, karena dalam mengutip sebuah jurnal maka kredibilitas dari karya ilmiah tersebut memiliki nilai yang lebih dibandingkan dengan sumber ilmiah lain.

Apabila memperhatikan dari berbagai keunggulan yang dimiliki jurnal elektronik atau e-journal membuat banyak perpusta-kaan khususnya perpustakaan Perguruan Tinggi tertarik untuk berlangganan jurnal elektronik melalui penyedia jasa layanan atau provider, seperti ProQuest, EBSCO, InfoTrac dan lain-lain. Dengan berlangganan berbagai macam subjek atau bidang ilmu seperti bidang kesehatan, 
sosial, ekonomi, dan sebagainya sesuai kebutuhan perpustakaan tersebut. Berdasarkan hal tersebut, banyak perpustakaan khususnya perpustakaan perguruan Tinggi saat ini yang mulai beralih ke koleksi elektronik, karena praktis dan aksesnya pun jauh lebih cepat dibandingkan koleksi tercetak.

Namun demikian untuk berlangganan jurnal elektronik tersebut tidaklah murah, sehingga tidah semua perpustakaan perguruan tinggi memiliki kemampuan yang sama. Oleh karena itu dibentuknya konsorsium e-journal yang diprakarsai oleh Forum Perpustakaan Perguruan Tinggi Indonesia (FPPTI) merupakan suatu program yang sangat solutif dalam mengatasi keterbatasan dan ketidak seimbangan sumber informasi yang dimiliki setiap Lembaga perpustakaan perguruan tinggi.

Dengan dibentuknya sistem konsorsium tersebut, biaya yang dikeluarkan untuk berlangganan jurnal elektronik jauh lebih murah dibandingkan dengan berlangganan sendiri. Program Konsorsium E-Journal ini diharapkan akan membantu meningkatkan kualitas perpustakaan perguruan tinggi anggota FPPTI Jawa Barat. Oleh karena demikian berangkat dari hal tersebut penulis tertarik untuk mengkaji tentang manajemen strategi pengembangan konsor-sium e-jurnal yang dilakukan FPPTI Jawa Barat.

\section{METODE PENELITIAN}

Penelitian ini menggunakan pendekatan kualitatif dengan jenis penelitian studi kasus yang akan mencoba melakukan eksplorasi secara mendalam terhadap kejadian, proses, aktivitas, terhadap satu atau lebih orang. Suatu kasus terikat oleh waktu dan aktivitas dan peneliti melakukan pengumpulan data secara mendetail dengan menggunakan berbagai prosedur pengumpulan data dan dalam waktu yang berkesinambungan (Sugiyono 2017, 5).

Studi kasus merupakan strategi yang lebih cocok bila pokok pertanyaan suatu penelitian berkenaan dengan how atau why, bila peneliti hanya memiliki sedikit peluang untuk mengontrol peristiwa-peristiwa yang akan
Yunus Winoto, Julian Abdilah dan Ute Lies Siti Khadijah diselidiki, dan bilamana fokus penelitiannya terletak pada fenomena kontemporer (masa kini) di dalam konteks kehidupan nyata (Robert K. Yin 2014, 1)

Melalui pengunaan pendekatan studi kasus, maka enelitian ini diharapkan dapat membantu peneliti dalam memahami peran Forum Perpustakaan Perguruan Tinggi Indonesia (FPPTI) Jawa Barat dalam mengembangkan program Konsorsium EJournal sebagai salah satu program kerjasama perpustakaan yang dilaksanakan oleh FPPTI Jawa Barat.

Dalam penelitian ini yang menjadi subjek penelitian yaitu pihak-pihak yang terlibat dalam melaksanakan program Konsorsium E-Journal yang bentuk oleh pengurus Forum Perpustakaan Perguruan Tinggi Indonesia (FPPTI) wilayah Jawa Barat. Sedangkan yang menjadi objek dalam penelitian ini adalah manajemen strategis

Data dalam penelitian ini terdiri dari data primer dan data sekunder. Adapun untuk data primer dalam penelitian ini diperoleh melalui observasi dan wawancara dengan para informan yang terkait dengan program konsorsium $e$ jurnal yang dilakukan FPPPT Jawa Barat. Sedangkan untuk data sekundernya diperoleh dari dokumen dan sumber literatur baik dalam bentuk tercetak, terekam maupun dalam bentuk elektronik.

Untuk Teknik pengumpulan datanya dilakukan melalui observasi (pengamatan), interview (wawancara) serta melalui studi dokumentasi. Sedangkan untuk analisis datanya dilakukan melalui tahap data reduction (reduksi data), data display (penyajian data), dan conclusion drawing/ verification (penarikan kesimpulan dan verifikasi).

\section{HASIL PENELITIAN}

Sebagaimana yang telah dikemukakan diawal tulisan ini, penelitian ini mencoba mengkaji tentang manajemen strategis program konsorsium e-journal yang dilakukan FPPTI Jawa Barat. Menurut J. David Hunger dan 
Thomas L. Wheelen dalam jurnal (Dewi dan Sandora 2019), manajemen strategi adalah serangkaian keputusan dan tindakan manajerial yang menentukan kinerja perusahaan dalam jangka panjang. Ada empat tahapan dalam manajemen strategis ini yakni tahap perencanaan, implementasi, evaluasi serta tahap pengendalian.

Berdasarkan hasil penelitian mengenai manajemen strategis program konsorsium $e$ journal yang dilakukan FPPTI Wilayah Jawa Barat dapat dikemukakan sebagai hasil berikut :

\section{Perencanaan Program Konsorsium E- Journal FPPTI Jawa Barat.}

Forum Perpustakaan Perguruan Tinggi Indonesia (FPPTI) Jawa Barat sebagai organisasi profesi yang bergerak di bidang perpustakaan, pada saat merencanakan program kerja Konsorsium E-Journal, manajemen konsorsium terlebih dahulu melakukan pengamatan melihat bagaimana kondisi lingkungan FPPTI Jawa Barat secara keseluruhan. Adapun jumlah anggota FPPTI Jawa Barat sebanyak 262 yang merupakan perwakilan dari berbagai latar belakang perguruan tinggi, baik perguruan tinggi negeri dan swasta yang ada di wilayah Jawa Barat.

Terjadinya perkembangan ilmu pengetahuan dan teknologi yang ditandai dengan semakin melimpahkan karya manusia baik dalam bentuk tercetak, terekam maupun dalam elektronik menuntut kesigapan dari para pengelola informasi dalam menangani hal ini. Namun demikian dengan adanya keterbatasan resources pada sebagian besar lembaga pengelola informasi termasuk dalam hal ini perpustakaan, maka perlu adanya kerjasama dinatara Lembaga perpustakaan dan pusat informasi lainnya. Hal ini dikarenakan tidak mungkin suatu perpustakaan akan mampu memenuhi seluruh kebutuhan para penggunanya ditengah-tengah melimpahnya informasi saat ini, sehingga konsep self sufficiency yang kerap dilakukan Lembaga perpustakaan menjadi tidak relevan lagi saat ini.

Berbicara tentang keterbatasan perpustakaan dalam penyediaan sumber informasi
Yunus Winoto, Julian Abdilah dan Ute Lies Siti Khadijah salah satu diantaranya jurnal. Nampaknya menjadi problem sebagian pengelola perpustakaan anggota FPPTI Jawa Barat. Tidak semua perpustakaan memiliki kemampuan anggaran dalam penyediaan sumber informasi terutama dalam berlangganan jurnal elektronik. Hal ini mengingat besarnya biaya yang harus dikeluarkan. Oleh karena itu gagasan untuk berlangganan e-journal dengan sistem konsorsium (bersama-sama) menjadi pilihan yang dirasakan cukup tepat. Sebagai gambaran dengan melakukan system konsorsium setiap perpustakaan hanya cukup mengeluarkan dana sekitar Rp. 5.000.000.- untuk setiap subjek jika berlangganan secara sendiri-sendiri akan dibutuhkan anggaran mencapai ratusan juta rupiah per subjek.

Dalam konteks manajemen strategis salah satu yang dilakukan dalam tahap perencanaan yaitu melakukan pengamatan terhadap lingkungan internal dan lingkungan eksternal pada organisasi FPPTI Jawa Barat. Pendekatan yang dilakukan dalam penelitian ini menggunakan analisis SWOT (Strengths, Weakeness, Opportunities, Threats).

Dilihat dari aspek Strenghts atau kekuatan, FPPTI Jawa Barat yang memiliki anggota FPPTI terbanyak se-Indonesia. Dilihat dari aspek Weakeness atau kelemahan pada program ini adalah belum semua perpustakaan anggota FPPTI memiliki sumber daya perpustakaan yang memadai, baik fisik maupun dana. Dilihat dari aspek peluang atau opportunities adanya kesempatan bagi anggota FPPTI Jawa Barat bisa berlangganan jurnal yang murah dibandingkan berlangganan sendiri. Sedangkan aspek Threats atau ancaman pada program ini adalah belum semua perpustakaan anggota yang peduli akan pelaksanaan program konsorsium e-journal, sehingga pimpinan perguruan tinggi anggota tidak bisa memberikan dana untuk konsorsium tersebut.

Setelah dilakukan pengamatan lingkungan dengan menggunakan pendekatan analisis SWOT langah selanjutnya dalah melakukan perumusan strategi pembangun-an rencana jangka panjang untuk menejemen efektif dari 
kesempatan dan ancaman lingkungan, dilihat dari kekuatan dan kelemahan perusahaan.

Melalui kerjasama berlangganan jurnal elektronik melalui sistem konsorsium ini, anggaran yang dikeluarkan untuk berlangganan jurnal elektronik ini bisa berkurang secara signifikan dibandingkan dengan berlangganan secara individu. Selain itu juga Konsorsium $E$ Journal yang dilaksanakan oleh FPPTI Jawa Barat ini juga bertujuan untuk meringankan beban anggota FPPTI Jawa Barat yang tidak memiliki kemampuan finansial untuk melakukan berlangganan sendiri.

Selain menjadi kebutuhan untuk pengguna perpustakaan, berlangganan jurnal elektronik sudah menjadi sebuah keharusan untuk setiap perguruan tinggi, karena hal tersebut juga merupakan bagian dari penilaian akreditasi perguruan tinggi yaitu ketersediaan akses secara online. Oleh karena itu perpustakaan juga diharuskan untuk dapat berlangganan jurnal elektronik.

Sasaran dari program konsorsium EJournal FPPTI Jawa Barat ini adalah seluruh anggota yang bernaung dibawah FPPTI Jawa Barat, baik itu Perguruan Tinggi Negeri maupun Perguruan Tinggi Swasta. Jumlah anggota FPPTI Jawa Barat per-maret 2019 sendiri berjumlah 262 anggota, terbanyak dari keseluruhan FPPTI se-Indonesia.

Dalam melaksanakan program tersebut, FPPTI Jawa Barat membuat Kerangka Acuan Kerja (KAK) atau istilahnya Team Of Reference (TOR). Kerangka Acuan Kerja (KAK) ini berisikan dokumen perencanaan kegiatan yang berisi penjelasan mengenai apa, mengapa, siapa, kapan, bagaimana dalam suatu kegiatan. Dengan kata lain, KAK yang dibuat berisikan penjabaran tentang latar belakang, maksud dan tujuan, hasil, periode pelaksanaan, spesifikasi, pelaksanaan, report, dan keberlanjutan program ini.

\section{Implementasi Program Konsorsium E- Journal FPPTI Jawa Barat}

Dalam melaksanakan program Konsorsium E-journal, tentu diperlukan sebuah tim
Yunus Winoto, Julian Abdilah dan Ute Lies Siti Khadijah manajemen atau organisator agar pelaksanaan program ini nantinya berjalan dengan baik. Secara tertulis, program Konsorsium e-journal FPPTI Jawa Barat ditugaskan kepada dua orang yang juga merupakan pengurus FPPTI Jawa Barat yaitu Wakil Ketua I FPPTI Jawa Barat Bidang Kerjasama dan Usaha yaitu Bapak Drs. H. Mahmudin, S.IP, M.M.Pd (Uninus) sebagai Ketua Program, dan Ibu Ubudiyah Setiawati (Unikom) sebagai sekretaris program.

Dalam menjalankan program konsorsium E-Journal ini, FPPTI Jawa Barat menggandeng salah satu penyedia jasa layanan jurnal elektronik atau provider yaitu ProQuest. Ada tiga bidang ilmu yang ditawarkan oleh ProQuest kepada Ketua Konsorsium FPPTI Jawa Barat, yaitu bidang ekonomi, bidang kesehatan, dan bidang sosial. Namun sejauh ini bidang yang dilanggankan oleh peserta Konsorsium FPPTI Jawa Barat hanya bidang kesehatan saja, karena hal tersebut disesuaikan dengan kebutuhan peserta yang berlangganan yang umumnya berasal dari perguruan tinggi yang berlatar belakang kesehatan.

Perihal anggaran Konsorsium E-Journal, FPPTI Jawa Barat menyerahkan sepenuhnya kepada anggota FPPTI yang menjadi peserta konsorsium. Maksudnya disini FPPTI Jawa Barat tidak memiliki anggaran tersendiri untuk program Konsorsium ini, FPPTI Jawa Barat hanya sebatas sebagai fasilitator yang menghubungkan antara pihak anggota FPPTI Jabar yang menjadi peserta konsorsium dengan pihak provider.

Masih berkaitan dengan implement-tasi program konsorsium e-journal, ada beberapa mekanisme yang dilakukan oleh FPPTI Jawa Barat agar program ini dapat terlaksana dengan baik yaitu :

1) FPPTI Jawa Barat membentuk dan menetapkan koordinator program Konsorsium E-Journal yang terdiri ketua dan sekretaris program yang ber-tanggung jawab terhadap pelaksanaan program kerja ini. Dan FPPTI Jawa Barat menugaskan dua orang yang juga merupakan pengurus FPPTI Jawa Barat yaitu Wakil Ketua I FPPTI Jawa Barat 
Bidang Kerjasama dan Usaha yaitu Bapak Drs. H. Mahmudin, S.IP, M.M.Pd (Uninus) sebagai ketua program, dan Ibu Ubudiyah Setiawati (Unikom) sebagai sekretaris program;

2) Kemudian ketua Konsorsium E-Journal FPPTI Jawa Barat menghubungi penyedia jasa layanan atau provider yang akan menjadi mitra kerjasama yaitu ProQuest, kemudian pihak ProQuest mengirimkan draft perjanjian berlang-ganan dan kemudian ditandatangani oleh kedua pihak;

3) Kemudian pihak ProQuest sebagai pihak penyedia jasa layanan juga mengirimkan proposal konsorsium kepada Ketua Konsorsium E-Journal FPPTI Jawa Barat. Isi dari proposal tersebut berisikan penawaran terkait pilihan subjek atau bidang ilmu yang akan dilanggankan, bidang ilmu yang dilanggankan tersebut berisikan 3 (tiga) pilihan subjek atau bidang ilmu yaitu (1) Ilmu Sosial (Humaniora, Hukum, Psikologi, Sosiologi, Komunikasi, Pendidikan, Politik, Kependudukan, Antropologi, dsb), kemudian (2) Kesehatan (Kesehatan, Kedokteran, Kebidanan, Keperawatan, Kesehatan Publik dan kebijakannya), serta (3) Ilmu Ekonomi (Bisnis, Manajemen, Wirausaha dan kebijakannya). Kemudian pada proposal yang dikirimkan oleh pihak ProQuest tersebut juga dibahas terkait akses pengunaan, statistik penggunaan dan harga berlangganan.

4) Setelah proposal didapatkan, selanjutnya Ketua Konsorsium E-Journal FPPTI Jawa Barat mulai menyusun surat penawaran kepada anggota yang ingin bergabung menjadi peserta konsorsium.

5) Kemudian Ketua Konsorsium E-Journal FPPTI Jawa Barat mulai melakukan sosialisasi kepada anggota, baik itu melalui pertemuan rutin FPPTI Jawa Barat maupun melalui sosialisasi lewat media sosial seperti grup WhatsApp. Pada tahapan sosialisasi ini pihak konsorsium juga menerima berbagai tanggapan terkait dengan pembiayaan, model kerjasama, subjek jurnal elektronik, serta konsekuensi dalam kerjasama tersebut.
Yunus Winoto, Julian Abdilah dan Ute Lies Siti Khadijah

6) Kemudian jika anggota FPPTI Jawa Barat tertarik dan bersedia untuk berlang-ganan $e$ journal dan menjadi peserta konsorsium, Ketua Konsorsium E-Journal akan pengiriman surat penawaran untuk bergabung menjadi anggota konsorsium.

Selanjutnya bagi anggota FPPTI Jawa Barat yang telah bersedia bergabung menjadi peserta untuk berlangganan jurnal elektronik, sebelum mereka dapat memanfaatkan akses $e$ journal tersebut, terlebih dahulu peserta konsorsium melakukan berbagai prosedur mulai dari prosedur administrasi di internal perguruan tinggi peserta yang bersangkutan, kemudian prosedur pembayaran kepada pihak konsorsium sebagai fasilitator, sampai nantinya dari pihak penyedia jasa layanan jurnal elektronik atau provider memberikan username dan password sebagai pembuka akses agar bisa memanfaatkan jurnal elektronik.

Setelah masa pengaksesan jurnal elektronik dilaksanakan dalam waktu satu tahun, kemudian bagi peserta yang ingin melakukan perpanjangan maupun penghen-tian berlangganan, peserta konsorsium harap mengkonfirmasikan kembali kepada pihak FPPTI Jawa Barat dan pihak penyedia jasa layanan satu bulan sebelum masa berlangganan tersebut berakhir.

Untuk prosedur perpanjangan berlangganan sendiri, tidak sebanyak seperti saat pertama kali berlangganan, prosedur yang dilakukan yaitu pihak peserta konsorsium kembali menerima surat penawaran dan kemudian menentukan subjek atau bidang ilmu yang akan dilanggankan. Kemudian setelah itu kemudian peserta konsorsium mentransferkan dana yang sudah diajukan pada tahun pertama berlangganan kepada pihak manajemen konsorsium e-journal FPPTI Jawa Barat untuk kemudian dana tersebut di transferkan kembali ke penyedia jasa layanan. Kemudian pihak peserta menunggu beberapa waktu sampai akses tersebut dibuka kembali. 


\section{Evaluasi Program Konsorsium E-Journal FPPTI Jawa Barat}

Bentuk dari evaluasi pelaksanaan program Konsorsium E-Journal dibuktikan yang pertama dalam bentuk usage report data atau statistik penggunaan yang diberikan oleh pihak ProQuest sebagai provider kepada pihak manajemen konsorsium dan peserta konsorsium. Pada statistik tersebut kita bisa melihat statistik pemanfaatan koleksi jurnal elektronik yang dimanfaatkan oleh perpustakaan yang menjadi peserta konsorsium, apakah pemanfaatannya maksimal atau justru pemanfaatannya minimal, semakin besar frekuensi penggunaan maka semakin maksimal pemanfaatannya, begitupun sebaliknya.

Berdasarkan data statistik penggunaan yang diperoleh pada periode pelaksanaan 2018-2019, subjek bidang ilmu yang dilanggankan oleh manajemen konsorsium FPPTI Jawa Barat adalah hanya bidang kesehatan saja, hal itu berdasarkan hasil survey kebutuhan yang dilakukan oleh FPPTI Jawa Barat. Kemudian untuk frekuensi pengguna dalam mengakses jurnal elektronik yang telah dilanggankan oleh peserta konsorsium tersebut bervariasi, ada yang mengakses jurnal tersebut sampai ribuan kali, dan ada juga yang mengaksesnya tidak sampai ratusan kali dari total 1039 judul. Berdasarkan data statistik yang diberikan oleh pihak ProQuest, hanya ada 3 peserta konsorsium dengan total akses nya melebihi 1000 kali pencarian, selebihnya kurang dari 1000 kali pencarian. STIKes Aisyiyah Bandung menjadi peserta yang paling banyak mengakses jurnal elektronik dengan 4350 kali total pencarian, sedangkan yang paling sedikit adalah STIKes Muhammadiyah Ciamis dengan 26 kali total pencarian.

Berdasarkan fakta di atas, tingkat akses $e$ journal masih dirasa kurang, manajemen konsorsium menduga kurang sosialiasi kepada pengguna menjadi salah satu sebab kenapa akses e-journal tersebut tidak maksimal, karena dengan sosialisasi yang maksimal, tentu penggunaan pun bisa maksimal tercapai, dan sosialisasi tersebut juga penting juga tidak semua pengguna mengerti tata cara mengakses
Yunus Winoto, Julian Abdilah dan Ute Lies Siti Khadijah e-journal. Hal tersebut juga diakui oleh salah satu peserta konsorsium bahwa sosialisasi yang mereka lakukan masih dirasa kurang karena alasan keterbatasan SDM untuk melakukan promosi e-journal tersebut.

Sementara itu dalam bentuk tingkat partisipasi peserta konsorsium e-journal FPPTI Jawa Barat, jumlah peserta yang berlangganan tiap tahun sejak pertama kali dilaksanakan pada tahun 2017-2018 cenderung mengalami penurunan. Hal tersebut dibuktikan dengan data yang diperoleh dari FPPTI Jawa Barat, pada tahun pertama pelaksanaan yaitu 2017-2018, partisipasi peserta justru tidak mencapai target yang ditetapkan oleh ProQuest sebagai provider pada tahun pertama berlangganan yaitu minimal 20 peserta, sementara pada tahun pelaksanaan tersebut, jumlah peserta yang berlangganan hanya mencapai 17 peserta saja. Namun atas proses negosiasi antara pihak manajemen dan ProQuest, akhirnya kegiatan konsorsium tersebut bisa dijalankan.

Selanjutnya bentuk dari evaluasi program Konsorsium E-Journal FPPTI Jawa Barat adalah dalam bentuk pelaporan dan umpan balik, pelaporan adalah penyampai-an perkembangan dan hasil kinerja, baik secara lisan maupun tulisan. Dengan adanya pelaporan ini di harapkan akan mampu mengkomunikasikan kepada stakeholders sejauh mana tujuan organisasi telah dilaksanakan. Sementara umpan balik menurut (Hunger and Wheelen 2003, 19) sangat diperlukan sebagai bentuk nyata dari pengawasan faktor-faktor penentuan penciptaan hasil strategi. Umpan balik bertujuan untuk mengamati kebelakang dari semua proses manajemen strategi yang digunakan dalam perusahaan atau organisasi.

Pada pelaksanaan evaluasi tersebut, sebagaimana yang telah dijelaskan oleh konsep di atas, tidak sesuai dengan fakta yang terjadi di lapangan. Hal ini dibuktikan dengan kurangnya transparansi pihak manajemen konsorsium $e$ journal FPPTI Jawa Barat dalam menginformasikan perkembangan pelaksanaan program konsorsium tersebut kepada para peserta, peserta konsorsium mengharapkan 
agar untuk kedepan informasi terkait program Konsorsium e-journal harusnya lebih terbuka lagi kepada anggota, terutama informasi terkait keterlibatan anggota, siapa saja yang masih berlangganan, berapa jumlah anggota yang masih berlangganan, dan harus itu ada reportnya.

Berdasarkan penjelasan diatas, dengan adanya usage report data atau data statistik sudah sejalan dengan konsep Manajemen Strategis yang dikemukakan oleh (Hunger and Wheelen 2003) yaitu evaluasi strategis yang proses yang melalui aktivitas-aktivitas perusahaan dan hasil kinerja dimonitor dan kinerja yang sesungguhnya dibandingkan dengan kinerja yang diinginkan, namun dalam hal pelaporan kinerja program, keterbukaan FPPTI Jawa Barat dirasa masih kurang terkait keterlibatan anggota dan informasi terkait peserta berlangganan.

Menurut (Akdon 2011, 84) Fokus utama dalam evaluasi strategi adalah pengukuran dan penciptaan mekanisme umpan balik yang efektif. Pengukuran kinerja merupakan tahap yang penting untuk melihat dan mengevaluasi capaian atau hasil pekerjaan yang telah dilakukan organisasi untuk mencapai tujuan yang menjadi sasaran pekerjaan tersebut. Evaluasi strategi menurut (Hunger and Wheelen 2003) sangat diperlukan sebab keberhasilan organisasi dewasa ini tidak menjadi jaminan keberhasilan organisasi di masa yang akan datang.

\section{SIMPULAN}

Berdasarkan hasil penelitian dapat disimpulkan bahwa :

1) Dalam tahap perencanaan, manajemen konsorsium e-journal FPPTI Jawa Barat terlebih dahulu melakukan pengamatan lingkungan dengan menganalisis dari aspek kekuatan, kelemahan, peluang, dan ancaman terhadap program konsorsium e-journal (Analisis SWOT). Kemudian hasil dari analisis tersebut selanjutnya akan menjadi acuan mana-jemen konsorsium untuk merumuskan strategi yaitu penetapan visi dan misi, penetapan tujuan, strategi dan
Yunus Winoto, Julian Abdilah dan Ute Lies Siti Khadijah kebijakan dalam melaksanakan program konsor-sium e-journal tersebut;

2) Dalam tahap implementasi, manajemen konsorsium e-journal FPPTI Jawa Barat setelah melaksanakan tahap analisis lingkungan dan perumusan strategi. Apa yang telah dirumuskan pada tahap perencanaan, kemudian hasil dari tahap perencanaan tersebut di wujudkan pada tahap implementasi. Implementasi strategi merupakan bagian kunci (key part) dari manajemen strategi kese-luruhan. Terdapat tiga tahapan pada proses implementasi strategi yang dilakukan oleh manajemen konsorsium e-journal FPPTI Jawa Barat yang sejalan dengan konsep Manajemen Strategis yang dikemukakan oleh (Hunger and Wheelen 2003), yaitu penetapan program, anggaran, dan prosedur.

3) Evaluasi program Konsorsium E-Journal FPPTI Jawa Barat yang berupa pengu-kuran kinerja yang ditampilkan dalam bentuk usage report atau statistik penggunaan serta laporan yang disampaikan oleh pihak manajemen dan peserta konsorsium terkait perkem-bangan program tersebut. Berdasarkan hasil evaluasi tersebut, tingkat peman-faatan jurnal elektronik yang belum maksimal, partisipasi peserta yang menurun setiap tahunnya serta trans-paransi manajemen yang masih kurang terbuka. Evaluasi program konsorsium e-journal tersebut berguna sebagai acuan untuk berbenah lebih baik kedepannya.

\section{DAFTAR PUSTAKA}

Akdon. 2011. Strategic Management for Educational Management (Manajemen Strategik Untuk Manajemen Pendidikan). Cet. 2. Bandung: Alfabeta, .

Arlinah I.R. 2002. "Manajemen Kerjasama Antar Perpustakaan." http://faculty.petra.ac.id/ arlinah /perpustakaan/kerjasama / kerjasama.pdf.

Basuki, Sulistyo. 1991. Pengantar Ilmu Perpustakaan. Jakarta: Gramedia Pustaka Utama. 
Departemen Pendidikan dan Kebudayaan. 2004. Perpustakaan Dan Masyarakat: Buku Pedoman. Jakarta: Departemen Pendidikan Nasional Direktorat Jenderal Pendidikan Tinggi.

Dewi, Ratna, and Meri Sandora. 2019. "Analisis Manajemen Strategi UIN Suska Riau Dalam Mempersiapkan Sarjana Yang Siap Bersaing Menghadapi MEA." El-Riyasah 10: 37-56.

Gultom, Hetty. 2013. Konsorsium Perpustakaan Di Indonesia. Medan: Perpustakaan Universitas Sumatera Utara.

Harisyah, Harisyah, and Muhammad Azwar. 2015. "Pemanfaatan Jurnal Elektronik Oleh Mahasiswa Fakultas Kedokteran Universitas Hasanuddin." Khizanah AlHikmah : Jurnal Ilmu Perpustakaan, Informasi, Dan Kearsipan 3 (1): 79-88. https://doi.org/10.24252/kah.v3i1a7.

Hasugian, Jonner. 2009. Dasar-Dasar Ilmu Perpustakaan Dan Informasi. Medan: USU Press.

Hunger, J. David, and Thomas L. Wheelen. 2003. Manajemen Strategis. Edited by Julianto Agung. Yogyakarta: Andi.

Jamaluddin. 2015. "Mengenal Elektronik Jurnal Dan Manfaatnya Bagi Pengembangan Karir Pustakawan." Pustakawan Madya Di UPT Pustakawan Unhas XIV (2): 38-44. http:// journal.unhas.ac.id/index.php/jupiter/ article/view/36/34.

Kamus Besar Bahasa Indonesia. 2008. Jakarta: Pusat Bahasa Departemen Pendidikan Nasional.

Moleong, Lexy J. 2008. Metodologi Penelitian Kualitatif. Bandung: Remaja Rosdakarya.

2011. Metodologi Penelitian Kualitatif. Bandung: Remaja Rosdakarya.

Pal, Jiban K, and Prabir Kumar Das. 2007. "Progress Through Partnership: Consortia Based e-Resource Subscription Initiatives in India." Workshop on Consortia Based Subscription of Online Resources (CBSOR-2007) 9433161580: 1-26.

Robert K. Yin. 2012. Studi Kasus Desain Dan Metode. Jakarta: Raja Grafindo Pustaka.
2014. Studi Kasus Desain Dan Metode. Jakarta: Rajawali Pers.

Robinson, Pearce. 1997. Manajemen Strategik, Formulasi, Implementasi, Dan Pengendalian. Jakarta: Bina Rupa Aksara.

Rusydi, Ibnu. 2014. "Pemanfaatan E-Journal Sebagai Media Informasi Digital." Iqra' 08 (02): 200-210.

Sugiyono. 2017. Metode Penelitian Kuantitatif, Kualitatif, Dan R\&D. Bandung: Alfabeta, .

Sutarno, N.S. 2003. Perpustakaan Dan Masyarakat. Jakarta: Yayasan Obor Indonesia.

Syahrial, and Rusina Pamuntjak. 2000. Pedoman Penyelenggaraan Perpustakaan. Revisi, Ce. Jakarta: Djambatan. 